\title{
Effectivity of Foot Care Education Program in Improving Knowledge, Self-Efficacy and Foot Care Behavior among Diabetes Mellitus Patients in Banjarbaru, Indonesia
}

\author{
Efektivitas Program Pendidikan Perawatan Kaki dalam Meningkatkan \\ Pengetahuan, Efikasi Diri dan Perilaku Perawatan Kaki Pasien Diabetes \\ Melitus di Banjarbaru, Indonesia
}

Mahdalena, Endang Sri Purwanti Ningsih

Banjarmasin Health Polytechnic Ministry of Health, Banjarmasin, Indonesia

\begin{abstract}
Diabetic foot problem in Indonesia remains a big problem and still needs an optimum concern. Foot care education is one of efforts that must be performed to prevent foot problem among diabetes mellitus patients. This study aimed to analyze effectivity of foot care education program in improving knowledge, self-efficacy and foot care behavior of diabetes patients in Banjarbaru. This study was quasi experimental with prepost test as conducted at primary health care in Banjarbaru in 2013. Foot care education program was provided to intervention group. Samples were 48 patients (32 persons in intervension group and 16 persons in control group) using purposive sampling technique. Variables measured were knowledge, self-efficacy and foot care behavior of diabetes mellitus patients. Intervension provided on respondents was in form of health education concerning foot care for twice. Every variable was measured twice before and after intervension. Knowledge test was measured using Diabetic Foot Care Knowledge Questionnaire, self-efficacy was measured by using Foot Care Confident Scale Self-Efficacy and foot care behavior was assessed using Behavior Foot Care Questionnaire. Data analysis used Manova. Results showed significant differences on knowledge level ( $p$ value $=0.001$ ), self-efficacy ( $p$ value $=0.000$ ) and foot care behavior $(p$ value $=0.000)$ before and after intervension.
\end{abstract}

Keywords: Education, foot care, self-efficacy

\begin{abstract}
Abstrak belum dan setelah intervensi.

Kata kunci: Pendidikan, perawatan kaki, efikasi diri

How to Cite: Mahdalena, Ningsih ESP. Effectivity of foot care education program in improving knowledge, self-efficacy and foot care behavior among diabetes mellitus patients in Banjarbaru, Indonesia. Kesmas: National Public Health Journal. 2016; 11 (2): 56-60. (doi:10.21109/kesmas.v11i2. 583)
\end{abstract}

Masalah kaki diabetik di Indonesia masih merupakan masalah besar dan masih memerlukan perhatian yang optimal. Edukasi perawatan kaki adalah salah satu upaya yang harus dilakukan dalam mencegah masalah kaki untuk pasien diabetes melitus. Penelitian ini bertujuan untuk menganalisis efektivitas program pendidikan perawatan kaki dalam meningkatkan pengetahuan, efikasi diri, dan perilaku perawatan kaki pasien diabetes di wilayah Banjarbaru. Jenis penelitian yang digunakan adalah quasi experimental dengan prepost test, dilakukan di puskesmas wilayah Banjarbaru tahun 2013. Kelompok intervensi diberikan program pendidikan perawatan kaki. Sampel berjumlah 48 pasien (32 orang kelompok intervensi dan 16 orang kelompok kontrol) menggunakan teknik purposive sampling. Variabel yang diukur adalah pengetahuan, efikasi diri, dan perilaku perawatan kaki pasien diabetes melitus. Perlakuan yang diberikan pada responden berupa pendidikan kesehatan tentang perawatan kaki sebanyak dua kali. Setiap variabel diukur dua kali sebelum dan setelah intervensi. Uji pengetahuan diukur menggunakan Diabetic Foot Care Knowledge Questionnaire, efikasi diri diukur menggunakan Foot Care Confident Scale Self-Efficacy, dan perilaku perawatan kaki dinilai menggunakan Behavior Foot Care Questionnaire. Analisis data menggunakan Manova. Hasil penelitian menunjukkan perbedaan yang signifikan pada tingkat pengetahuan (nilai $p=0,001)$, efikasi diri (nilai $p=0,000)$ dan perilaku perawatan kaki (nilai $p=0,000)$ se-

Correspondence: Mahdalena, Banjarmasin Health Polytechnic Ministry of Health, Mistar Cokrokusumo street No.1A Banjarbaru Banjarmasin, Phone: +62511-4773267,e-mail: lenaf4dll@gmail.com

Received: December $12^{\text {th }} 2015$

Revised: June $18^{\text {th }} 2016$

Accepted: August $11^{\text {th }} 2016$

Copyright @ 2016, Kesmas: National Public Health Journal, p-ISSN: 1907-7505, e-ISSN: 2460-0601, Accreditation Number: 56/DIKTI/Kep/2012, http://journal.fkm.ui.ac.id/kesmas 


\section{Introduction}

Several serious complications can be suffered by patients of diabetes mellitus, such as kidney failure or blindness, yet the biggest complication is complication related to foot. Of average of mortality rate within five years after suffering from diabetic foot, $43-74 \%$ get foot amputation as this condition related to bad habit, bad management of diabetes, and lack of preventive actions. ${ }^{1}$

In Indonesia, diabetic foot problem remains a big problem and still needs an optimum concern. Most of treatment of diabetes mellitus patients is always due to diabetic foot. Data of Cipto Mangunkusumo Public Hospital in 2007 showed that of 327 diabetes mellitus patients hospitalized at internal disease treatment room, 111 patients were diagnozed with diabetic foot ulcers. Based on such data, the most often etiology were neuropathy $(62.5 \%)$ and peripheral artery disease $(16.7 \%)$. Moreover, extrinsic factors that take a role in diabetic foot pethogenesis are trauma $(65.2 \%)$, shoes $(21.7 \%)$, etc $(13 \%)$. Output of diabetic foot patients are amputation $(35 \%)$, death $(15 \%)$ and get recovered with deformities $(50 \%)$. Condition of diabetes mellitus patients after amputation is still very bad and died in three years after amputation $(14.3 \%)^{2}$

Foot ulcer suffered by diabetes mellitus patients does not only affect on physical changes of the sufferers, but also affect their daily life. ${ }^{3}$ In literature study concerning quality of life of diabetes mellitus patients with foot ulcer, several studies both qualitative and quantitative say that foot ulcer suffered by diabetes mellitus patients gives negative effects to their life, which are the decreasing physical function, psychological status and social status.

Health policies in Indonesia nowadays more put forward on independence of Indonesian people in managing their health, so any health programs today is more increasing in terms of promoting and preventive actions. As well as in solving any diabetic foot problems in Indonesia, several strategies are needed to solve the problem including preventive actions, cooperations of any diciplines in the execution, monitoring and education for diabetes mellitus patients by health professionals. Foot care is one of actions that should be conducted to prevent foot problem especially for diabetes mellitus patients. Empowerment of diabetes mellitus patients in conducting foot care independently is something that should be performed by nurses. Comprehensive approach integrating patient education and preventive foot care may decrease frequency and morbidity of diabetic foot lesion threat. ${ }^{4}$

Several studies showed effectivity of foot care education to cognitive and behavioral changes as well as decrease of foot disorder incidence such as ulcer through patient education in forms of lecture, workshop, skill exercise, modification programs and followup by phone. ${ }^{5}$
In Banjarbaru City region, South Kalimantan Province, there were data that diabetes mellitus sufferers in 2013 were as many as 1,960. Then the number of sufferers increased in 2014 ranked at $14^{\text {th }}$ place as the largest case of disease in Banjarbaru City with 3,483 sufferers (Banjarbaru Health Agency).

Based on prior study conducted at Sungai Besar Primary Health Care, Banjarbaru, on 10 diabetes mellitus patients undergoing outpatient, 7 patients stated that they did not do foot care including foot checkup, washing, the use of lotion and nail care. Two persons did not maintain foot hygiene, 10 persons said that they never received education/counseling concerning foot care. Based on observation, several primary health care in Banjarbaru City were not yet to perform educational actions concerning foot care, and checking up diabetes mellitus patients' foot condition was still not yet a regular activity while physical checkup. Primary health care is the leading health care center, so if diabetes mellitus foot care educational actions can be well performed, the decrease of referral number of diabetes mellitus sufferers to hospitals due to diabetic foot complications may occur.

This study aimed to analyze effectivity of foot care education programs in improving knowledge, self-efficacy and behavior of diabetes mellitus patients in diabetic foot care at primary health care in Banjarbaru region.

\section{Method}

This study used quasi experimental prepost test with control group as conducted on two groups of study, namely intervention group and control group. This study aimed to analyze effectivity of foot care education programs in improving knowledge, self-efficacy and behavior of diabetes mellitus patients in diabetic foot care at primary health care in Banjarbaru region, with hypothesis that foot care education programs could improve knowledge, self-efficacy and behavior of diabetes mellitus patients in foot care.

Subjects of study were all diabetes mellitus patients at primary health care in Banjarbaru region including Banjarbaru, Cempaka, Sungai Besar Primary Health Care. Samples were all diabetes mellitus patients at Banjarbaru Primary Health Care that met criteria as many as 48 respondents consisting of 32 respondents in the intervension group as 22 persons were taken from Cempaka Primary Health Care and 10 persons were taken from Banjarbaru Primary Health Care. Meanwhile, there were 16 respondents in the control group consisting of 10 persons taken from Cempaka Primary Health Care and 6 persons taken from Sungai Besar Primary Health Care.

Samples were taken by purposive sampling technique with inclusion criteria including diabetes mellitus type II patients aged $<60$ years, having reading and writing 
abilities, not having visual problem (diabetic retinopathy according to eye doctor), physically and mentally able to participate, never get amputated, never have diabetic ulcer records before and today (degree 0/in accordance with Wagner's classification).

Independent variables in this study were foot care education program as conducted within three weeks (in three education sessions). Each education session was performed within 60 minutes using peer group. Dependent variables were knowledge, self-efficacy and foot care behavior. Knowledge was measured by questionnaire consisting of 11 questions adopted from Diabetic Foot Care Knowledge Questionnaire (DFCKQ). ${ }^{6}$ Maximum score for knowledge test was 11. Questionnaire to self-efficacy consisted of 12 questions adopted from Foot Care Confident Scale Self-Efficacy (FCSS). ${ }^{7}$ Maximum score for self-efficacy was 12 . Test consisting of 12 questions from Behavior Foot Care Questionnaire was used toward variable foot care behavior. ${ }^{8}$ Total score for foot care behavior was 48 . Data analysis was conducted by assessing pretest and posttest for variable knowledge, self-efficacy and foot care behavior as analyzed using Kruskal-Wallis test. All variables were simultaneously analyzed in multivariate with Manova test.

\section{Results}

Some respondents were women, aged $>58$ years, elementary school education level, employed status and suffering diabetes mellitus $<5$ years. The complete results could be seen in Table 1. Educators of diabetes conducted counseling in three locations of study, namely Cempaka, Banjarbaru and Sungai Besar Primary Health Care. Health counseling/education was performed in three education sessions. Counseling was performed with peer group consisting of $10-15$ persons. Each session took place approximately 60 minutes using lecture and simulation methods.

Respondents' knowledge of foot care was stated in form of increase of knowledge score (pre-posttest) on intervension group as many as $23(71.83 \%)$. Self-efficacy of respondents was stated in form of increase of self-efficacy score on the intervension group as many as 28 $(87.5 \%)$. Foot care behavior score (pre-posttest) on the intervension group was $25(78.12 \%)$ (Table 2$)$.

\section{Discussion}

Knowledge of foot care for diabetes mellitus patients is basis in managing their foot as preventive action of diabetic foot complications. Clients's ability in understanding a disease is a basis to know principles in term of prevention/care. diabetes mellitus patients' knowledge of foot care can be increased by providing health education. 8

Based on results of this study, on the intervension group before foot care education program provided, most respondents $(71.9 \%)$ already had category of good level of knowledge, yet most in the control group still had low level of knowledge $(56.3 \%)$. Most of respondents' education background in both groups had elementary school education level. However, a person's knowledge level was not only obtained through education level, but it could be obtained through experience, seeing from diabetic foot sufferers or based on information got from mass media. ${ }^{9}$

Study above also showed that the less knowledge of foot care in the control group certainly would result the lack of understanding the necessity of efforts/actions in care, which could affect the less respondents' awareness of preventive action of diabetic foot complications. Increase of foot care knowledge is very needed by diabetes mellitus patients to prevent the incidence of diabetic foot complications.

Table 1. Distribution of Respondents Based on Age, Sex, Work, Period of Suffering from Diabetes Mellitus

\begin{tabular}{|c|c|c|c|c|c|}
\hline \multirow{2}{*}{ Characteristics } & \multirow{2}{*}{ Category } & \multicolumn{2}{|c|}{ Group } & \multirow{2}{*}{ Total } & \multirow{2}{*}{$\%$} \\
\hline & & Intervension & Control & & \\
\hline \multirow[t]{2}{*}{ Age } & $<50$ years old & 15 & 5 & 20 & 41.6 \\
\hline & $\geq 50$ years old & 17 & 11 & 28 & 58.4 \\
\hline \multirow[t]{2}{*}{ Sex } & Male & 12 & 9 & 21 & 43.8 \\
\hline & Female & 20 & 7 & 27 & 56.2 \\
\hline \multirow[t]{5}{*}{ Education } & Uneducated & 1 & 3 & 4 & 8.3 \\
\hline & Elementary school & 17 & 12 & 5 & 35.4 \\
\hline & Junior high school & 5 & 2 & 7 & 14.6 \\
\hline & Senior high school & 7 & 2 & 9 & 18.8 \\
\hline & Higher education & 7 & 4 & 11 & 22.9 \\
\hline \multirow[t]{2}{*}{ Work } & Employed & 22 & 8 & 30 & 62.5 \\
\hline & Unemployed & 10 & 8 & 18 & 37.5 \\
\hline \multirow[t]{4}{*}{ Period of suffering from DM } & $<1$ years & 5 & 8 & 13 & 27.1 \\
\hline & $1-5$ years & 18 & 2 & 20 & 41.7 \\
\hline & $6-10$ years & 6 & 4 & 10 & 20.8 \\
\hline & $>10$ years & 3 & 2 & 5 & 10.4 \\
\hline
\end{tabular}


Table 2. Increase of Knowledge, Self-Efficacy and Foot Care Behavior on the Control Group and Evaluation

\begin{tabular}{|c|c|c|c|c|c|c|c|c|c|c|}
\hline \multirow[t]{2}{*}{ Group } & \multirow[t]{2}{*}{ Knowledge Level } & \multicolumn{2}{|c|}{$\begin{array}{c}\text { Increase of } \\
\text { Knowledge Score }\end{array}$} & \multirow[t]{2}{*}{ p Value } & \multicolumn{2}{|c|}{$\begin{array}{l}\text { Improvement of } \\
\text { Self Efficacy }\end{array}$} & \multirow[t]{2}{*}{ p Value } & \multicolumn{2}{|c|}{$\begin{array}{c}\text { Improvement of } \\
\text { Foot Care Behavior }\end{array}$} & \multirow[t]{2}{*}{ p Value } \\
\hline & & f & $\%$ & & f & $\%$ & & f & $\%$ & \\
\hline \multirow{3}{*}{$\begin{array}{l}\text { Intervension group } \\
(\mathrm{n}=32)\end{array}$} & Decreasing & 6 & 18.38 & \multirow[t]{6}{*}{0.001} & 2 & 6.25 & \multirow[t]{6}{*}{0.000} & 4 & 12.5 & \multirow[t]{6}{*}{0.000} \\
\hline & Constant & 3 & 9.76 & & 2 & 6.25 & & 3 & 9.76 & \\
\hline & Increasing & 23 & 71.87 & & 28 & 87.5 & & 25 & 78.12 & \\
\hline \multirow{3}{*}{$\begin{array}{l}\text { Control group } \\
(n=16)\end{array}$} & Decreasing & 6 & 37.5 & & 9 & 56.25 & & 11 & 68.75 & \\
\hline & Constant & 6 & 37.5 & & 3 & 18.75 & & 2 & 12.5 & \\
\hline & Increasing & 4 & 25 & & 4 & 25 & & 3 & 18.75 & \\
\hline
\end{tabular}

a test with Manova

Results of this study confirmed any significant difference toward knowledge level on the intervension group after the provision of foot care education compared to the control group. According to the result, foot care education program was significantly effective in increasing knowledge of foot care among diabetes mellitus patients. Result of this study was supported by several findings stating that education intervension effectively could increase knowledge and foot care behavior. ${ }^{10-12}$

Based on results, effective foot care education program could significantly increase score of self-efficacy. This study was similar to study that conducted experiment study to patients of cardiovascular disease, which resulted that double increase of self-efficacy occurred on the intervension group after cardiac diet education provided. ${ }^{11}$ Another study was also conducted on 138 diabetes mellitus patients in Zahedan, Iran in which the study resulted that effective self-efficacy training improved knowledge, attitude and behavior of self-care which also affected to values of HBA1c and fasting blood glucose. ${ }^{13}$

Improvement of health behavior to a positive was the final aim of an education program or health education by officers. Good foot care behavior effectively could prevent the incidence of diabetic foot complications. Results of study conducted to 396 diabetes mellitus type II patients stated that foot care intervension thorugh education program was proven statistically able to reduce risk of incidence of foot problems among diabetes patients, such as foot lesions, ulcers, whereabouts of mushroom growth, ingrown nail and foot deformities on the intervension group compared to the control group. ${ }^{14}$

Improvement of foot care behavior in the intervension group could be due to any increase of knowledge and self-efficacy scores after intervension of foot care education was performed. Self-efficacy influences relation between self-ability in doing activities and self-management. ${ }^{15}$ The rise of good foot care behavior was based on willingness, attitude and high motivation as well as adequate knowledge, therefore patients were expected to be able to perform actions of footcare in their daily life at home. Results of this study was in line with study conducted to 63 diabetes mellitus patients at Arifin Achmad Public Hospital in Pekanbaru, Riau which said that there was a positive relation between knowledge $(\mathrm{p}$ value $=$ 0.00 ) and attitude ( $\mathrm{p}$ value $=0.03$ ) with diabetic foot care behavior. ${ }^{15}$ Knowledge was one of factors that support in daily self-care because by adequate knowledge, a person would understand his/her ill condition and hopefully be able to manage himself/herself to always have healthy lifestyle, so blood glucose was controlled. Similar study was also conducted by Perrin, Swerissen and Payne to 96 diabetes mellitus patients suffering from peripheral neuropathy, which stated that there was a positive relation between foot care self-efficacy beliefs and actual foot care behavior. ${ }^{16}$

\section{Conclusion}

There is a significant difference between scores of knowledge, self-efficacy and diabetes mellitus patients' behavior before and after following foot care education program.

\section{Recommendation}

Nurses at primary health care should provide foot care education periodically to diabetes mellitus patients. Patients should always care of their foot to avoid diabetic ulcers.

\section{References}

1. Robbins JM, Strauss G, Aron D, Long J, Kuba J, Kaplan Y. Mortality rates and diabetic foot ulcers: is it time to communicate mortality risk to patients with diabetic foot ulceration?. Journal of American Podiatric Medical Association. 2008; 98 (6): 489-94.

2. Perkumoulan Endrokinologi Indonesia. Modul pelatihan penatalaksanaan kaki diabetik bagi dokter spesialis penyakit dalam. Jakarta: Perkeni; 2009.

3. Goodridge D, Trepman E, Embil JD, Daughty D. Health-related quality of life in diabetik patients with foot ulcers: literature review. Journal of Wound, OStomy, and Continence Nursing. 2005; 32(6): 368-77.

4. Frykberg RG, Zgonis T, Armstrong DG, Driver VR, Giurini JM, Kravitz SR, et al. Diabetic foot disorder: a clinical practice guideline. The 
Journal of Foot \& Ankle Surgery. 2006; 45(5): 2 -3.

5. Singh N, Armstrong DG, Lipsky BA. Preventive foot ulcer in patients with diabetes. The Journal of American Medical Association. 2005 [ cited 12 Aug 2008]; 293 (2): 217-28. Available from: http://jama.amaassn.org/cgi/content/full/293/2/217.

6. Pollock RD, Unwin NC, Connoly V. Knowledge and practice of foot car in people with diabetes. Diabetes Research and Clinical Practice. 2004; 64: 117-22.

7. Sloan H. Developing and testing of the foot care confident scale. Jurnal of Nursing Measurement. 2002; 10: 207-18.

8. Vileikyte L, Gonzales J, Leventhal H, Peyrot M, Rubin R, Garoww A, et al. Patient interpretation of neuropathy (PIN) questioner: an instrument for assessment of cognitive and emotional factor associated foot self care. Diabetes Care. 2006; 29(12): 2617-24.

9. Bastabel S. Prinsip-prinsip pengajaran dan pembelajaran. Jakarta: EGC; 2002.

10. Corbett CF. A randomised pilot study of improving foot care in home health patients with diabetes. Diabetes Educator. 2003; 29: 273-82.

11. Valk GD, Kreigsman DMW, Assendelf WJJ. Patient education for pre- venting diabetic foot ulceration. Cochrane Database of Systemic Reviews. 2005; 25 (1): 1-43.

12. Vatankhah N, Khamseh ME, Naudeh YJ, Aghili R, Baradaran HR, Haeri NS. The effectiveness of foot care education on people with type 2 diaetes in Tehran Iran. Primary Care Diabetes. 2009; 3: 73-7.

13. Carson JA, Gillham MB, Kirk LM, Reddy ST, Battles JB. Enhancing self efficacy and patient care with cardiovascular nutrition education. American Journal of Preventive Medical. 2002; 23(4): 296-302.

14. Litzelman DK, Slemenda CW, Langeferd CD, Hays LM, Welch MA, Bild Diane E, et al. Reduction of lower extremity clinical abnormalities in patients with non insulin dependent diabetes mellitus. Annals of Internal Medicine. 1997; 119(1): 36-41.

15. Hasanli Y, Amir F, Utomo W. Hubungan tingkat pengetahuan dan sikap klien diabetes mellitus terhadap perawatan kaki diabetes. Jurnal Keperawatan Profesional Indonesia. 2010; 2(2): 50-5.

16. Perrin BM, Swerissen H, Payne C. The association between foot-care self efficacy beliefs and actual foot-care behaviour in people with peripheral neuropathy: a cross-sectional study. Journal of Foot and Ankle Research. 2009; 2:3. 